\title{
Bismuth Subsalicylate
}

National Cancer Institute

\section{Source}

National Cancer Institute. Bismuth Subsalicylate. NCI Thesaurus. Code C1020.

A bismuth salt of salicylic acid. Little absorbed from the gastrointestinal tract, bismuth subsalicylate exerts a local effect on the gastric mucosa, coating it and protecting it from the corrosive effects of acid and pepsin. This agent also has local antimicrobial properties. ( $\mathrm{NClO4})$ 